\title{
English for Tour Guide: A Need Analysis of a Contextual-Based Language Teaching
}

\author{
Ni Made Ratminingsih ${ }^{1 *}$, Made Suardana ${ }^{2}$, and Anak Agung Ngurah Yudha Martin ${ }^{3}$ \\ ${ }^{1}$ English Education Department, Universitas Pendidikan Ganesha, 81116 Singaraja-Bali, Indonesia \\ ${ }^{2}$ English Department, Universitas Pendidikan Ganesha, 81116 Singaraja-Bali, Indonesia \\ ${ }^{3}$ Hospitality Department, Universitas Pendidikan Ganesha, 81116 Singaraja-Bali, Indonesia
}

\begin{abstract}
This paper reports the results of need analysis of English for Specific Purposes (ESP) for local tour guides in two villages in Buleleng regency. This research is a descriptive qualitative study involving 56 tour guides, in which 30 were based in Ambengan village and 26 others were posted in Sambangan village. There were three instruments applied to obtain the research data such as observation sheet, questionnaire, and interview guide. Findings from the observation showed that the two villages had waterfalls and terraced rice fields as the main potencies. Additionally, the questionnaire specifying the target need showed that both groups had low speaking skill $(56.05 \%)$ even the rest of them $(43.95 \%)$ understood English, but was not able to speak English at all. Furthermore, they all required oral English, speaking (69\%) and listening (24.5\%). Seen from learning need, they demanded conversation $(90.5 \%)$ as the most important learning experience. The results from interview proved that 92.5\% local guides had no academic background in English. From those findings, it can be summed up that they need contextual-based English learning to accomplish their jobs in a more professional way through non formal education.
\end{abstract}

Keywords: contextual-based language learning, English for Specific Purposes, need analysis, tour guide

\section{Introduction}

Tourism cannot be separated from the role of tour guides. They are members of the community who have working opportunity in tourism sector becoming members of tourism group or Kelompok Sadar Wisata. This group is formed in order to develop the natural potency of the place. Thus, they have a very significant role to facilitate what travelers need and to guide them while traveling in an area. In order to serve them well, language plays an important role in order to conduct communication in general and hospitality service in particular. It is believed that communication skill is greatly an important element of hospitality industry, both oral and written skill [1]. Good tour guides have to be knowledgeable and resourceful, and they have to know how to communicate efficiently and effectively [2]. In addition, they should be skillful because they are the most valuable assets in tourism companies. In many ways, a guide is the 'facade' of a business or company.

*Corresponding author: made.ratminingsih@undiksha.ac.id 
Many foreign visitors tend to view them as representatives of the region or country. Besides that, tour guides have tasks to recognize the social environment, arrange transportation, interpret, handle problems, insulate travellers from difficulties and make the environment safe for tourists because they act as 'intermediaries' between tourists and the 'unknown' environment [3]. In addition to this, tour guides have important roles in tourism. They are responsible for leading and interpreting in the context of environment [4].

However, the reality often shows that many tour guides have inadequate proficiency in English, but they are brave enough to conduct guiding. This phenomenon commonly happens in developing countries like in Indonesia. Thus, a need analysis regarding the target situation and present situation should be conducted. It is considered as a factor that drives the development of ESP curriculum [5]. Furthermore, needs analysis can be clarified in two ways, a target situation analysis (TSA) and present situation analysis (PSA) [6]. TSA is a need analysis which focuses on students' needs at the end of the language course. The TSA is the stage at which 'good enough' competence for the job is reached. Present situation analysis (PSA), on the other hands, seeks to establish what the students are like at the start of their language course, investigating their strengths and weaknesses. Henceforth, there are two kinds of needs, needs which come from outside as the target needs derived from the target situation analysis, while needs which come from inside as the felt needs derived from present situation analysis.

There are three basic sources of information, namely the students themselves, the language teaching establishment, and the 'user-institution', for example the students' place of work [6]. Some information that can be traced from the learners are ranging from their levels of ability, resources (financial and technical), and their views on language teaching and learning, attitude toward English and learning and use of a foreign language. As well, information can also be obtained from the surrounding society and culture.

Needs analysis has significant role in developing English [7]. It is considered as the key essence of ESP [8]. Hence, it will help the teachers to make a number of planning decisions, to group the students, to decide the strategies and learning activities, and to capitalize on students' strength and motivation in ESP course [9]. Moreover, the role of needs analysis for ESP is concerning on the use of vocational or specific language needs [10]. ESP as the English teaching and learning in the context of ESL or EFL aims to be used in particular purposes [11]. Therefore, the purpose of an ESP course is to enable learners to function adequately in a target situation, that is the situation in which the learners will learn language based on their needs.

Being able to conduct their tasks successfully, tour guides should possess good competence in English to communicate with their guests, especially related to the context where they use English with them. Contextual teaching and learning is able to enhance the learners to understand concept while practicing to speak with one another [12]. Additionally, if people learn something based on context, the context will give meaning to the content. Hence, learning is meaningful when what is learned is able to be used in the real life context [13].

Previous research on the use of contextual-based learning found that contextual teaching and learning had a significant effect on learners reading skill, besides, it could motivate them in learning and help them to understand the materials [14]. Furthermore, it was proved there was a significant effect toward students' writing competency after getting the treatment [15]. Specifically in ESP, a research discovered that there was a significant effect of using contextual expressions on pre-text learning, oral and writing interaction and word-meaning inferring [16]. Another research also revealed that students in hotel required special English needs and interests in order to motivate them as well as build their selfconfidence [17]. In addition, it was found that both verbal and non-verbal communication skills used by tour guides were good in handling the customer [18]. Despite several 
research conducted previously on contextual-based language teaching, a similar research is still needed in order to analyze its needs for local tour guide who use English as a foreign language. This research is different from the previous ones, which focuses on needs analysis of local tour guides in Ambengan and Sambangan village in Sukasada District before developing training materials which are relevant to their needs. Therefore, this study is beneficial to be conducted in order to help local tour guides in two villages to improve their English skills.

\section{Method}

This study was a descriptive qualitative research, conducted within one month in the beginning of year 2017. It involved 56 subjects of tour guides who were divided into two tourism groups, named Kelompok Sadar Wisata (short for Pokdarwis) Banten Sari, in Ambengan Village consisting of 30 members, and Pokdarwis Tunjung Mekar in Sambangan Village comprising 26 members. The instruments utilized to collect data were observation, questionnaire, and interview guide. Observation was held to see the existing potencies of the two tourism villages and the ways the tour guides perform their duties in guiding the guests. Questionnaire was delivered to find out the target needs and learning needs, while the interview was held to the leaders of two groups and several members to identify their educational background, tasks that they have to hold, and problems they faced when handling and communicating to the guests. The data were collected through several steps, such as (1) observing the tourism objects and availability of facilities and activities in the two tourism villages, (2) interviewing the leaders and several members of their present situation in terms of strengths and weaknesses, and (3) distributing the questionnaire to all of 56 tour guides. Then, the collected data were analyzed descriptively by counting the percentage of the responses.

\section{Results and Discussion}

The result of observation shows that the existing potencies in the two tourism villages are rather similar. In Ambengan there are 6 waterfalls (Jembong, Puncak Sari, Pucuk, Kroya, Kembar, and Aling-aling) while in Sambangan there are 7 waterfalls (Pucuk, Kroya, Kembar, Aling-aling, Canging, Dedari, and Cemara). Among those waterfalls, there are 4 of them under the possession of two villages namely Kroya, Kembar, Pucuk, and AlingAling waterfalls. The activities normally conducted in these places are trekking, sightseeing, swimming, cliff jumping, sliding, and taking pictures. Besides that, there are 3 other tourism destinations, terraced rice field, guardian temple, and plantation (clove, durian, mangosteen, coconut). Some activities that are usually done are trekking, sightseeing, having lunch, taking pictures in terraced rice fields, while offering Balinese canangsari, praying in guardian temple, and sightseeing, taking pictures, tasting icedcoconut water and flesh in plantation.

The data show that among 30 tour guides of tourism group in Ambengan village, the majority of them $(73.2 \%)$ only have primary education and only very few of them $(2 \%)$ have educational background in tourism. Meanwhile, among 26 tour guides of tourism group in Sambangan village, the data show that their educational background tends to be better since some of them (26.9\%) are graduates of the tertiary level of institution. From 7 of them, 3 are graduates of English Education Department, and 2 of them is a graduate of hospitality and tourism department respectively. Some others (26.9\%) are only graduates of primary education. In terms of tasks, both groups of local tour guides mainly do activities such as handling the guests' arrival in the office, telling tour itinerary, guiding the guests to 
the tourism objects, conducting tour activities in the tourism object, handling complaints during and after trekking tour. Dealing with the problems, in Ambengan there has not been given English training by the government while in Sambangan the local tour guides have been trained by government and social community service from a university. But, both trainings were really relevant with tour guides' needs.

Table 1. Target and learning needs

\begin{tabular}{|c|l|l|}
\hline No & \multicolumn{1}{|c|}{ Statements } & Percentage \\
\hline 1 & Why do you need English? & \\
\hline & a. To communicate with foreigner & $82.45 \%$ \\
\hline 2 & What level of English do you have? & $51.05 \%$ \\
\hline & a. Speak a little bit of English & $34.00 \%$ \\
\hline & b. Understand English but cannot speak well & $5 \%$ \\
\hline & c. Understand English and is able to give response minimally & $5 \%$ \\
\hline 3 & d. Able to speak English fluently & \\
\hline & What kind of English skills do you need to be developed? & $24.5 \%$ \\
\hline & a. Listening & $69.00 \%$ \\
\hline 4 & b. Speaking & $\begin{array}{l}\text { What kinds of learning experience do you need? (the respondents } \\
\text { may give more than one answer) }\end{array}$ \\
\hline & a. Discussion & $18 \%$ \\
\hline & b. Conversation & $90.5 \%$ \\
\hline
\end{tabular}

The result of questionnaire shows that most of the local tour guides need English for communicating with foreigner, it is proved by the percentage $82.45 \%$ from both groups' respondents. In terms of English level, $51.05 \%$ of the respondents in both groups were able to speak a little bit of English and only 5\% of local tour guides were able to give response minimally. Moreover, the majority of respondents from both groups required oral English (listening and speaking) to help them to communicate with their guests since $69 \%$ of them chose speaking skill while $24.5 \%$ in listening. The fourth item, mostly, both groups demanded conversation as their learning experience while they were learning English.

Based on the result of observation, it is obvious that the two villages have potentials such as waterfalls, terraced rice fields, guardian temples, and plantations. Regarding this, they are classified as ecotourism areas. Besides the objects, the facilities provided are suitable for the activities, such as safety guards and swimming equipment for trekking, swimming, cliff jumping, and sliding. Other activities normally done by the tourists are sightseeing and taking pictures. Additionally, it was observed that there are medication plantations e.g. turmeric which has function to cure mild illness and organic and inorganic dustbins which purposes to preserve the nature. This echoes the definition of ecotourism that it is a kind of sustainable tourism which has conservative function towards the environment by developing the indigenous community [19]. Ecotourism has beneficial impacts such as preserving the nature [20, 21, 22] increasing economy [23] foreign exchange and jobs [20], and encouraging and develop local communities in terms of social aspects [20].

Considering the findings interview and questionnaire, it is clearly shown that the local tour guides of both Pokdarwis have lack of ability to speak English. It is proven by the result of questionnaire that only $10 \%$ of them could speak English fluently. This problem is crucial since as a tour guide, they need to describe a lot about place and tell the history of a place. This is related to the statement which emphasize that a guide has to be capable in delivering information about tourism destination as well as initiating good conversation with the guests [2]. Besides that, the result of interview showed that there was an English course held in both groups, Ambengan and Sambangan. The English course was about 
general English which tended to be less relevant since $100 \%$ of respondents confirmed that they needed English materials which are related to their jobs. Meanwhile, based on questionnaire, the local tour guides wanted materials that make them to learn. Therefore, the result of needs analysis plays an important role as the foundation of material development. It is in line with statements that needs analysis will help the teachers to make appropriate materials, to decide the strategies and learning activities, and to capitalize on students' strength and motivation [9]. In addition to the finding, the local tour guides also need to learn English contextually in order to accomplish their tasks. This supports arguments [13] that people need to learn a language based on the context since it promotes meaningful learning. In relation to this, contextual teaching and learning helps the language learners to understand the language concept [12]. This means that contextual-based materials are very important to conducted to the local tour guides because they are meaningful when what is learned is able to be used in the real life context.

\section{Conclusion}

There are three things that can be inferred based on the findings of needs analysis. Firstly, waterfalls and terraced rice fields are the main potencies of the ecotourism which have benefits to increase working opportunities, social and economic development of local communities, national income, and preserve the natural resources. Secondly, the target needs indicates low English speaking skill, very small number of local tour guides who have English education background, limited training programs and resources which is relevant with their tasks as tour guides. Lastly, the local tour guides require contextualbased training materials to improve their English speaking skill.

The authors would like to thank Universitas Pendidikan Ganesha Singaraja for the support toward this research. Special appreciation is also forwarded to the management of the tourism groups in the two villages for the cooperation.

\section{References}

1. M. K. Bobanovic, AlmaTourism, 4 (2011)

2. T. O'Brien, H. S. Ham, Toward professionalism in tour guiding-a manual for trainer (US Agency, University of Idaho, 2012)

3. H.Q. Zhang, I. Chow, I, Tourism Management, 25, 1 (2004)

4. J. M. Chilembwe, V. Mweiwa, IJER, 2, 9 (2014)

5. M.J. Hossain, J.PU, 2, 2 (2002)

6. R. Richterich, J.L. Chancerel, Identifying needs of adults learning a foreign language, (Pergamon Press, Oxford, 1980)

7. N. Prachanant, Procedia Soc. Behav. Sci., 66 (2012)

8. M. Rahman, UJER, 3, 1 (2015)

9. J. C. Richards, Communicative language teaching today (CUP, Cambridge, 2001)

10. N. Rahmani, T. Pushpanathan, IJAMR, 2, 10 (2015)

11. S.M. Otilia, ES, 2, 1 (2015)

12. S. Annisa, EEJ, 6, 4 (2015)

13. E.B. Johnson, Contextual teaching and learning; What it is and why it's here to stay (Corwin Press Inc, Thousand Oak California, 2002) 
14. K. Khaefiatunnisa, JEE, 3, 1 (2015)

15. L. Suparman, A.A.I.N. Marhaeni, N. Dantes, e-Journal Program Pascasarjana Undiksha Program Studi Pendidikan Bahasa Inggris, 1 (2013)

16. H. Tian, JLTR, 6, 6 (2015)

17. H.T.M. Albakrawi, IJELT, 1, 1 (2013)

18. N. Suardhana, Nitiasih, A.J. Putra, e-Journal Program Pascasarjana Undiksha Program Studi Pendidikan Bahasa Inggris, 3, 1 (2013)

19. M. Das, B. Chatterjee, IIM Kozhikode Society \& Management Review, 4, 2 (2015)

20. J. F. Koens, C. Dieperink, M. Miranda, Environ. Dev. Sustain., 11 (2009)

21. K.C. Anup, R. Kedar, P.S. Ramesh, Int. J Sust. Dev. World, 22, 3 (2015)

22. R. Butarbutar, Soemarno, J. Ind. Tour. Dev. Std., 1, 3 (2013)

23. R. Staiff, R. Bushell, P. Kennedy, JOST, 10, 2 (2002) 